University of Nebraska - Lincoln

DigitalCommons@University of Nebraska - Lincoln

Nutrition and Health Sciences -- Faculty

Publications

Nutrition and Health Sciences, Department of

2009

Content Validity of Nutrition Diagnostic Term Involuntary Weight

Loss

Paula K. Ritter-Gooder

University of Nebraska-Lincoln, pgooder@windstream.net

Nancy M. Lewis

University of Nebraska--Lincoln, nlewis2@unl.edu

Follow this and additional works at: https://digitalcommons.unl.edu/nutritionfacpub

Part of the Dietetics and Clinical Nutrition Commons

Ritter-Gooder, Paula K. and Lewis, Nancy M., "Content Validity of Nutrition Diagnostic Term Involuntary Weight Loss" (2009). Nutrition and Health Sciences -- Faculty Publications. 12.

https://digitalcommons.unl.edu/nutritionfacpub/12

This Article is brought to you for free and open access by the Nutrition and Health Sciences, Department of at DigitalCommons@University of Nebraska - Lincoln. It has been accepted for inclusion in Nutrition and Health Sciences -- Faculty Publications by an authorized administrator of DigitalCommons@University of Nebraska - Lincoln. 
Published in Journal of the American Dietetic Association 109:9, Supplement 1 (September 2009; ADA Food \& Nutrition Conference \& Expo), p. A22; doi:10.1016/j.jada.2009.06.049 Copyright (C) 2009 American Dietetic Association; published by Elsevier Inc. Used by permission.

Published online August 21, 2009; presented at Poster Session: "Professional Skills; Nutrition Assessment; Medical Nutrition Therapy," Sunday, October 18, 2009.

\title{
Content Validity of Nutrition Diagnostic Term Involuntary Weight Loss
}

\author{
P. Ritter-Gooder and N. M. Lewis \\ Department of Nutrition and Health Sciences, University of Nebraska-Lincoln, Lincoln, NE
}

\author{
Learning Outcome \\ Describe validity of the diagnostic term, Involuntary Weight Loss.
}

\section{Objective}

The purpose of this study was to validate content of the Nutrition Diagnostic Term NC3.2 Involuntary Weight Loss using expert raters.

\section{Design/Subjects}

This descriptive survey invited all Board Certified Specialists in Gerontological Nutrition (CSG) to participate by mail. An instrument was developed that included the definition, etiologies, and signs and symptoms (s/s) of the diagnosis with items added from literature review. CSG rated how common or characteristic each item is to the diagnosis using a 5 point Likert scale. A weighted response for each item was used to calculate a Diagnostic Content Validity (DCV) score. DCV scores of 0.80 and above were classified as major characteristics, 0.50 to 0.799 were minor characteristics, and those scoring below 0.50 were unrepresentative of the diagnosis. A mean total DCV score was calculated using the major and minor characteristics. Dietitians were asked to comment on clarity and completeness of the language.

\section{Results/Discussion}

Seventy three percent of CSG $(n=110)$ had participated, $43 \%$ percent had an MS degree or higher level of education. Reported years of practice in gerontological nutrition were $15 \pm 10$ years (mean $\pm \mathrm{SD}$ ). The DCV score was 0.80 for the definition, 0.63 for the etiologies, and 0.70 for s/s. Total DCV score for the diagnostic term was 0.69 . Thirty six percent and $40 \%$ of the CSG recommended adding language to etiologies and s/s respectively. Results indicate the majority of items were valid to the diagnostic term but responses for adding items need further investigation. 